\title{
Functional Morphology of the Spermatogenesis of Gir Bulls
}

\author{
Daniel F. M. Silva1, Fabio J. C. Faria'1, Fernando H. G. Furtado', Carlos A. C. Fernandes², \\ Juliana C. B. Silva ${ }^{3}$, Adriano Garcia ${ }^{4}$, Deiler S. Costa ${ }^{*}$ (1) \\ ${ }^{1}$ Federal University of Mato Grosso do Sul, Campo Grande, Brazil \\ ${ }^{2}$ University José do Rosário Vellano, Alfenas, Brazil \\ ${ }^{3}$ Embrapa Pantanal, Corumbá, Brazil \\ ${ }^{4}$ Brazilian Zebu Breeders Association, ABCZ, Campo Grande, Brazil \\ ${ }^{5}$ Nucleus of Animal Production and Reproduction (NUPRA), Campo Grande, Brazil \\ Email: *deilercosta@yahoo.com.br
}

How to cite this paper: Silva, D.F.M., Faria, F.J.C., Furtado, F.H.G., Fernandes, C.A.C., Silva, J.C.B., Garcia, A. and Costa, D.S. (2020) Functional Morphology of the Spermatogenesis of Gir Bulls. Agricultural Sciences, 11, 1081-1094.

https://doi.org/10.4236/as.2020.1111070

Received: September 26, 2020

Accepted: November 20, 2020

Published: November 23, 2020

Copyright $\odot 2020$ by author(s) and Scientific Research Publishing Inc. This work is licensed under the Creative Commons Attribution International License (CC BY 4.0).

http://creativecommons.org/licenses/by/4.0/

\section{(c) (i) Open Access}

\begin{abstract}
The purpose of this study was to evaluate the functional morphology of the spermatogenesis of Gir bulls, with emphasis on the testicular biometry and testicular parenchyma histomorphometry. Testicular fragments from eight Gir bulls were used. The fragments were fixed by tissue perfusion with Karnovsck's solution, and inclusion was subsequently performed using glycol methacrylate. Histological sections of $4 \mu \mathrm{m}$ were made and stained with a $1 \%$ toluidine blue-sodium borate solution. The mean age of the bulls was $8.0 \pm$ 1.3 years and the mean body weight was $467.5 \pm 26.7 \mathrm{~kg}$. Testicular weight was $289.2 \pm 30.5 \mathrm{~g}$ on average, and the average gonadosomatic index was $0.12 \% \pm 0.02 \%$. The seminiferous tubules, Leydig cells, stroma, and intertubular tissue composed $80.9 \% \pm 1.7 \%, 5.4 \% \pm 1.3 \%, 13.7 \% \pm 1.1 \%$, and $19.1 \%$ $\pm 1.7 \%$ of the total testicular weight, respectively. The mean length of the seminiferous tubule per gram of testicle was $17 \pm 0.8 \mathrm{~m}$. Losses during spermatogonia mitosis averaged $75.5 \% \pm 3.22 \%$, while losses were $30.6 \% \pm 8.17 \%$ during the meiotic phase, which resulted in an average total loss of $81.49 \% \pm$ $2.58 \%$ of cells during the entire process of spermatogenesis. The average daily sperm production per gram of parenchyma was $28.0 \times 10^{6}$ cells. It was concluded that the histometric measurements of testicular parameters in the Gir breed are within the averages reported for other zebu cattle breeds.
\end{abstract}

\section{Keywords}

Spermatogonia, Leydig, Sertoli, Testicle 


\section{Introduction}

The Brazilian cattle herd was formed by animals with no defined breed in the $19^{\text {th }}$ century. These animals, originating from European countries (Iberian Peninsula), came with the first colonizers of Brazil. The reproduction of these animals without any selection criteria produced individuals with low productive and reproductive performance, as was verified at the time. Moreover, the dominant taurine genetics were challenged by huge problems with endo- and ecto-parasites, causing great concern to rural producers. With this scenario came the need to import cattle of Indian origin, which is rustic and better adapted to the tropical environment [1] [2].

The beginning of the mid- $20^{\text {th }}$ century saw the largest numbers of zebu cattle imported from India to Brazil. These imports generated an enormous impact on Brazilian cattle ranching [3] [4]. Currently, about $80 \%$ of the Brazilian herd is of zebu origin [5]. Specifically, the Gir breed arrived in Brazil in 1911 and is fully inserted into the historical context of the development of the country, with Brazil reserving the status of having the largest commercial herd of zebuine cattle in the world [5] [6]. Gir cattle are the zebuine breed with the highest milk productivity in tropical climates due to efficient thermoregulation characteristics that have allowed increased levels of milk production.

However, despite the importance of the Gir breed in Brazil, most studies focusing on andrological reproductive characteristics and the reproductive fitness of bulls are based on the Nelore breed [7].

The spermatogenic process, in turn, is a synchronous and regular physiological system of cell division and differentiation, during which a trunk spermatogonia is gradually differentiated into a highly-specialized haploid cell: the spermatozoid. This sequence of modifications occurs in the seminiferous tubules and lasts about 40 to 60 days in most studied mammals [8].

The three classes of germ cells involved in spermatogenesis are: spermatogonia, spermatocytes, and spermatids. In adults, spermatogenesis is a continuous process that can be divided into three distinct phases: mitosis, meiosis, and spermiogenesis or differentiation, with each phase characterized by morphological and biochemical changes in the components of the cytoplasm and cell nucleus [9].

Spermatogenic cells are arranged in the seminiferous tubules in an organized and well-defined manner, forming cellular associations that characterize the stages of the CSE. In most studied mammals, the arrangement of the stages of the CSE is segmented and there is usually only one stage per cross-section of the tubule, except in humans and monkeys [10].

The CSE in a given segment can be defined as the period between the disappearance of a given stage and its reappearance in this same segment [11]. The duration of the CSE is generally constant for a given species, but varies from one species to another [10].

Although the spermatogenic process of Nelore bulls was well-defined in Car- 
doso [12], there are few publications that describe the spermatogenic process of Gir bulls, which, despite occurring in lower numbers in Brazil compared to the Nelore breed, is a breed that effectively participates in this context, especially in crosses with European dairy breeds.

This study aimed to evaluate the functional morphology of the spermatogenesis of Gir bulls, with emphasis on the testicular biometry and histomorphometry of the testicular parenchyma.

\section{Materials and Methods}

Eight Gir bulls that were pure of origin, sexually mature, and did not present any alterations to the genital organs or to the semen upon examination were used. The animals were $8.0 \pm 1.3$ years old and weighed $467.5 \pm 26.7 \mathrm{~kg}$ on average.

Immediately after the orchiectomy and epididymis dissection, the testicles were weighed on a precision scale and perfused with Karnovisck solution for tissue fixation. Inclusion was performed using glycol methacrylate (Kit Historesin, Leica Biosystems-Nussloch, Germany), as described in Costa et al. [13]. Histological sections of four micrometers in thickness were obtained using a glass knife in a rotating microtome. The sections were then stained with toluidine blue-sodium borate 1\% solution, and the slides were mounted with Entellan ${ }^{\circledast}$ (Merck, Germany).

The gonadosomatic index (GSI) was determined by calculating the ratio between body weight and the weight of the two testicles, and the results were presented as percentages.

The weight of the testicular parenchyma was obtained by subtracting the weight of the tunica albuginea and the mediastinum from the testicular weight, which were estimated from the dissection of the stored testicles. Due to the fact the density of testicles is very close to one [14], the weight was considered to be equal to the volume.

The average diameter of the seminiferous tubules was calculated by measuring the diameter of at least 20 tubule cross-sections per animal. The sections were chosen to be as circular as possible, regardless of their stage. Measurements were made using the "Image J 1.34s" morphometry software [15].

The height of the seminiferous epithelium was measured for the same cross-sections as the diameter of the seminiferous tubules. The distance from the basal membrane to the luminal edge was considered. At least two measurements were taken per cross-section and the average of these was taken as the result.

The total length of the seminiferous tubules was calculated according to the methodology outlined in Attal and Courot [16]. The cross-sectional area was measured with the aid of Image J software. At least 10 seminiferous tubule cross-sections were measured, regardless of their stage.

The tubular diameter and total volume of the seminiferous tubules were estimated considering a linear shrinkage factor of $5 \%$ [17]. The total length of the seminiferous tubules was expressed in meters. 
The volumetric proportions of the testicular parenchyma components were obtained with the aid of the Image J software, using a grid with 420 intercessions considered as points. The proportions of the following components of the testicular parenchyma were computed: Leydig cells, stroma (cells, blood and lymphatic vessels, and connective tissue fiber), and seminiferous tubules. At least 20 randomly selected fields were examined by horizontal scanning of the histological sections. Thus, the volumetric proportions, expressed as percentages, were calculated over a minimum of 8400 points per testicle. The magnification used for this analysis was 400 times.

The populations of each cell type of the seminiferous epithelium were estimated by counting the nuclei of the germ cells and the nucleoli of Sertoli cells in at least 20 cross sections in stage 1 of the CSE, categorized by the method of tubular morphology [18]. The following cell types were counted: type A spermatogonia, primary spermatocytes in preleptotene/leptotene, primary spermatocytes in pachytene, rounded spermatids, and Sertoli cells.

The count was corrected for the mean nuclear diameter and thickness of the section using the Abercrombie [19] formula modified by Amann [20]. Due to the fact that Sertoli cells have an irregular nucleus, the correction of their number was made using the mean nucleolar diameter.

Mean nuclear or nucleolar diameter was obtained by measuring at least 10 nuclei of each germ cell type or 10 nucleoli of Sertoli cells per animal. As type A spermatogonia have ovoid or slightly elongated nuclei, the mean of the largest and smallest nuclear diameter measurement was used for this calculation.

The cell population counts of the seminiferous epithelium and mean nuclear or nucleolar diameter measurements were taken with the help of Image J software, using digitized microscopic images.

The intrinsic spermatogenesis yield was estimated based on the ratios found among the corrected cell numbers obtained from the seminiferous tubule cross-sections. The following ratios were calculated:

- Efficiency coefficient of spermatogonia mitoses-ratio of the number of primary spermatocytes in preleptotene/leptotene to the number of type A spermatogonia during stage 1 of the CSE.

- Meiotic yield-the ratio of the number of rounded spermatids to the number of primary spermatocytes in the pachytene during stage 1 of the CSE.

- General spermatogenesis yield-ratio of the number of rounded spermatozoa to the number of type A spermatozoa during stage 1 of the CSE.

In order to evaluate the occurrence of cell loss during meiotic prophase, the ratio between the number of primary spermatocytes in the pachytene and the number of primary spermatocytes in the pre-leptotene/leptotene during stage 1 of the CSE was also calculated.

Daily sperm production was estimated based on the number of rounded sperm per Sertoli cell in stage 1, the Sertoli cell population per testicle, and the frequency and duration of stage 1, according to the formula developed by Amann 
and Almquist [21]. The duration of stage 1 was considered to be 4.38 days [22].

To determine the daily sperm production per gram of testicular parenchyma, the total daily sperm production was divided by the weight of the two testicles free of the tunica albuginea and mediastinum, i.e. divided by the weight of the testicular parenchyma multiplied by two.

The statistical analyses were performed in the BioEstat 3.0 statistical software program [23]. All results were presented as means, standard deviations, and coefficients of variation.

\section{Results}

Data on the ages, body and testicular weights, testicular parenchyma weights, and gonadosomatic index of the bulls are presented in Table 1.

The means of the tubular diameter, height of seminiferous epithelium, and tubular length per gram of testicle values are shown in Table 2. The coefficients of variation were low for these three variables, showing the homogeneity of these parameters among the different animals of the Gir breed.

The volumetric proportions of the testicles occupied by the seminiferous tubules and the intertubular tissue, which includes Leydig cells and stroma, are shown in Table 3. The proportion of seminiferous tubules in the animals ranged by only $2.1 \%$, while the proportion of Leydig cells occupying the intertubular tissue ranged by $24 \%$.

The populations of the different cell types during stage 1 of the SEC estimated in the eight Gir breed bulls are presented in Table 4. Although the number of Sertoli cells showed little variation (3.7 to 4.4), the number of rounded spermatozoa varied widely among the animals (76.7 to 99.5$)$.

Table 1. Age, body weight, testicular weight, parenchyma weight, and gonadosomatic index (GSI) of eight Gir bulls.

\begin{tabular}{cccccc}
\hline Animal & $\begin{array}{c}\text { Age } \\
(\text { years })\end{array}$ & $\begin{array}{c}\text { Body Weight } \\
(\mathbf{k g})\end{array}$ & $\begin{array}{c}\text { Total Testicular } \\
\text { Weight }(\mathbf{g})^{*}\end{array}$ & $\begin{array}{c}\text { Testicular Parenchyma } \\
\text { Weight }(\mathbf{g})^{* *}\end{array}$ & $\begin{array}{c}\text { GSI } \\
(\%)\end{array}$ \\
\hline 1 & 10 & 492 & 272.6 & 250.1 & 0.11 \\
2 & 9 & 468 & 311.5 & 286.0 & 0.13 \\
3 & 8 & 475 & 244.6 & 224.4 & 0.10 \\
4 & 8 & 492 & 337.2 & 309.3 & 0.14 \\
5 & 7 & 435 & 295.5 & 270.9 & 0.14 \\
6 & 7 & 421 & 304.7 & 279.9 & 0.14 \\
7 & 9 & 467 & 255.2 & 233.7 & 0.11 \\
8 & 7 & 490 & 292.2 & 268.3 & 0.12 \\
Average \pm sd & $8.0 \pm 1.3$ & $467.5 \pm 26.7$ & $289.2 \pm 30.5$ & $265.3 \pm 28.1$ & $0.12 \pm 0.02$ \\
C.V & $16 \%$ & $5.7 \%$ & $10.5 \%$ & $10.6 \%$ & $16.6 \%$ \\
\hline
\end{tabular}

${ }^{*}$ Weight of only one testicle ${ }^{* *}$ Total testicular weight-albuginea and mediastinum weight. ${ }^{* *}$ Coefficient of variation. $\mathrm{C} . \mathrm{V}=$ standard deviation/mean. 
Table 2. Average tubular diameter $(\mu \mathrm{m})$, height of seminiferous epithelium $(\mu \mathrm{m})$, and tubular length per gram of testicle ( $\mathrm{m}$ ) of eight Gir bulls.

\begin{tabular}{cccc}
\hline Animal & $\begin{array}{c}\text { Diameter of the } \\
\text { Seminiferous Tube* }(\mu \mathrm{m})\end{array}$ & $\begin{array}{c}\text { Height of the Seminiferous } \\
\text { Epithelium }(\mu \mathrm{m})\end{array}$ & $\begin{array}{c}\text { Tubular length } \\
\text { per } \mathbf{g} / \text { Testicle }(\mathrm{m})\end{array}$ \\
\hline 1 & 243.7 & 69.6 & 17.3 \\
2 & 254.9 & 70.4 & 16.3 \\
3 & 236.8 & 66.8 & 18.5 \\
4 & 252.4 & 71.1 & 16.1 \\
5 & 245.1 & 69.5 & 17.6 \\
6 & 233.7 & 72.3 & 16.8 \\
7 & 249.6 & 68.8 & 17.1 \\
8 & 250.1 & 67.9 & 16.5 \\
Average \pm sd & $245.8 \pm 7.5$ & $69.6 \pm 1.8$ & $17.0 \pm 0.8$ \\
C. $^{* *}$ & $3 \%$ & $2.5 \%$ & $4 \%$ \\
\hline
\end{tabular}

${ }^{*}$ Using a linear shrinkage coefficient of $5 \%$, according to Amann [17]. ${ }^{* *}$ Coefficient of variation. C.V $=$ standard deviation/mean.

Table 3. Volumetric proportions (\%) of testicular parenchyma constituents in eight Gir bulls.

\begin{tabular}{ccccc}
\hline Animal & $\begin{array}{c}\text { Seminiferous tubules } \\
(\%)\end{array}$ & $\begin{array}{c}\text { Leydig cells } \\
(\%)\end{array}$ & $\begin{array}{c}\text { Stroma* }^{*}(\%) \\
\text { Intertubular tissue } \\
(\%)\end{array}$ \\
\hline 1 & 80.8 & 4.7 & 14.5 & 19.2 \\
2 & 83.1 & 4.6 & 12.3 & 16.9 \\
3 & 81.5 & 4.1 & 14.4 & 18.5 \\
4 & 80.5 & 4.9 & 14.6 & 19.5 \\
5 & 82.9 & 5.3 & 11.8 & 17.1 \\
6 & 79.4 & 6.3 & 14.3 & 20.6 \\
7 & 80.8 & 5.2 & 14.0 & 19.2 \\
8 & 78.0 & 8.1 & 13.9 & 22.0 \\
Average \pm sd & $80.9 \pm 1.7$ & $5.4 \pm 1.3$ & $13.7 \pm 1.1$ & $19.1 \pm 1.7$ \\
C. $V^{* *}$ & $2.1 \%$ & $24 \%$ & $8 \%$ & $9 \%$ \\
\hline
\end{tabular}

${ }^{*}$ Stroma comprises: cells and fibers of the connective tissue, nerves, blood, and lymphatic vessels. ${ }^{*}$ Coefficient of variation. C.V $=$ standard deviation/mean.

Table 5 presents the ratios between the cell types present during stage 1 of CES, equivalent to mitotic performance (PL/L: A), meiotic performance (Air: $\mathrm{PQ})$, primary spermatocyte ratio in prophase I (PQ: PL/L), and general spermatogenesis performance (Air: A). The cellular losses presented in parentheses in Table 5 are calculated based on the fact that bovines have six generations of spermatogonia $\left(\mathrm{A}_{1-3}\right.$, In and $\left.\mathrm{B}_{1-2}\right)$, as described in Cardoso [12].

Total daily sperm production per gram of testicular parenchyma is shown in Table 6. 
Table 4. Populations of different cell types during stage 1 of the cycle of seminiferous epithelium in eight Gir bulls.

\begin{tabular}{cccccc}
\hline Animal & S & A & PL/L & FP & Air \\
\hline 1 & 4.0 & 1.8 & 27.2 & 34.0 & 93.3 \\
2 & 3.9 & 2.3 & 34.6 & 36.5 & 94.0 \\
3 & 3.8 & 2.1 & 28.9 & 34.2 & 76.7 \\
4 & 3.9 & 1.9 & 30.4 & 30.9 & 95.3 \\
5 & 4.3 & 1.8 & 25.1 & 31.8 & 90.9 \\
6 & 3.7 & 2.1 & 29.9 & 34.8 & 99.5 \\
7 & 4.4 & 2.0 & 35.3 & 34.8 & 88.9 \\
8 & 4.1 & 1.7 & 33.5 & 29.6 & 97.4 \\
Average \pm sd & $4.0 \pm 0.2$ & $2.0 \pm 0.2$ & $30.6 \pm 3.6$ & $33.3 \pm 2.3$ & $92.0 \pm 7.0$ \\
C. $\mathrm{V}^{* *}$ & $5 \%$ & $10 \%$ & $11.7 \%$ & $7 \%$ & $7.6 \%$ \\
\hline
\end{tabular}

S-Sertoli cells; A-type A spermatogonia; PL/L-primary spermatocytes in preleptotene/leptotene; $\mathrm{PQ}$ - primary spermatocytes in pachytene; Air-rounded spermatids. ${ }^{*}$ Values corrected according to Amann [20]. ${ }^{*}$ Coefficient of variation. C.V $=$ standard deviation $/$ mean.

Table 5. Ratios between the corrected germ cell numbers per seminiferous tubule cross-section in stage 1 of the Gir bull cycle of seminiferous epithelium. Numbers in parentheses are the percentage losses during mitotic and meiotic divisions of germ cells and losses of general spermatogenesis yield.

\begin{tabular}{ccccc}
\hline Animal & PL/L: A & Air: PQ & PQ: PL/L & Air: A \\
\hline 1 & $15.11(76.39 \%)$ & $2.74(31.40 \%)$ & 1.25 & $51.83(79.75 \%)$ \\
2 & $15.04(76.49 \%)$ & $2.58(35.62 \%)$ & 1.05 & $40.87(84.04 \%)$ \\
3 & $13.76(78.50 \%)$ & $2.24(43.93 \%)$ & 1.18 & $36.52(85.73 \%)$ \\
4 & $16.00(75.00 \%)$ & $3.08(22.90 \%)$ & 1.02 & $50.16(80.41 \%)$ \\
5 & $13.94(78.21 \%)$ & $2.86(28.54 \%)$ & 1.27 & $50.50(80.27 \%)$ \\
6 & $14.24(77.75 \%)$ & $2.86(28.52 \%)$ & 1.16 & $47.38(81.49 \%)$ \\
7 & $17.65(72.42 \%)$ & $2.55(36.14 \%)$ & 0.99 & $44.45(82.64 \%)$ \\
Average \pm sd & $19.71(69.21 \%)$ & $3.29(17.74 \%)$ & 0.88 & $57.29(77.62 \%)$ \\
C. $\mathrm{V}^{* *}$ & $15.68 \pm 2.06$ & $2.78 \pm 0.33$ & $1.10 \pm 0.14$ & $47.38 \pm 6.59$ \\
\hline
\end{tabular}

S-Sertoli cells; A-type A spermatogonia; PL/L-primary spermatocytes in preleptotene/leptotene; PQ-primary spermatocytes in pachytene; Air-rounded spermatids. ${ }^{*}$ Values corrected according to Amann $[20] .{ }^{* *}$ Coefficient of variation. C.V $=$ standard deviation $/$ mean.

Table 6. Total daily sperm production $\left(\times 10^{9}\right)$ and sperm production per gram of testicle parenchyma $\left(\times 10^{6}\right)$ in eight Gir bulls.

\begin{tabular}{|c|c|c|}
\hline Animal & $\begin{array}{l}\text { Total Daily Sperm } \\
\text { Production }{ }^{*}\left(\times 10^{9}\right)\end{array}$ & $\begin{array}{l}\text { Daily Sperm Production/g of } \\
\text { Testicular Parenchyma }{ }^{* *}\left(\times 10^{6}\right)\end{array}$ \\
\hline 1 & 14.4 & 28.9 \\
\hline 2 & 15.6 & 27.3 \\
\hline
\end{tabular}




\section{Continued}

\begin{tabular}{ccc}
\hline 3 & 11.3 & 25.3 \\
4 & 16.9 & 27.4 \\
5 & 15.3 & 28.5 \\
6 & 17.8 & 32.9 \\
7 & 14.6 & 26.2 \\
8 & 12.9 & 27.6 \\
Average \pm sd & $14.9 \pm 2.1$ & $28.0 \pm 2.3$ \\
C. $V^{* * *}$ & $14 \%$ & $8.2 \%$ \\
\hline
\end{tabular}

${ }^{*}$ Total daily sperm production of both testicles. ${ }^{*}$ Calculated according to Amann and Almquist [21]. ${ }^{* * *}$ Coefficient of variation. $\mathrm{C} . \mathrm{V}=$ standard deviation/mean.

\section{Discussion}

In this study, the testicles of eight Gir cattle bulls with definitive genealogical registers (pure of origin) were analyzed. The bulls had an age difference of three years between the youngest and the oldest, and a difference of approximately seventy kilograms between the lightest and the heaviest (Table 1). These age and weight ranges were chosen in order to avoid prepubescent or senile animals, or those with some kind of nutritional deficiency.

In Gir bulls, the tunica albuginea and the mediastinum occupied approximately $8.2 \%$ of the testicular volume. In studies on testicular physiology, testicular albuginea and mediastinum volumes are discounted from testicular mass to calculate testicular parenchyma, because this tissue does not contribute directly in spermatogenesis or androgenesis. In most domestic species, the volumetric proportion of the testicular albuginea and mediastinum is generally about $10 \%$ [8]. The present study demonstrated the same percentage as observed in other studies (Table 1) [20] [24].

To validate the comparison of testis weight as well as the proportion of tunica albuginea in different studies, the animals investigated must be about the same age. This is necessary because, although the phase of highest testis development lasts until sexual maturity, it continues to grow afterwards at a lower rate [25]. Therefore, any discrepancies in results must be carefully analyzed to prevent methodological differences from invalidating comparisons [26].

The gonadosomatic index in the Gir breed found in the present study $(0.12 \%)$ was similar to that observed in other studies performed on zebuine cattle. Andreussi et al. [1] also found a gonadosomatic index of $0.12 \%$ in Gir animals, with an average of $0.13 \%$ in the Nelore, Nelore mocho, Gir, Tabapuã, and Guzerá breeds. In young taurine animals of the Shorthorn breed, Swierstra [27] obtained an GSI of $0.8 \%$.

For each species, the testis size is determined in response to a variety of factors, besides the primary influence imposed by the body size. However, the number of Sertoli cells, established at the testis development cycle, is the major 
factor for determination of testis size and sperm production in a given species [28]. It is usual to observe differences up to $50 \%$ for testis weight among sexually mature animals, even for those species genetically selected, as in bovine [29]. Opposed to what is observed for testis developmental phase it is not usual to find significant correlation between testis weight and body weight in adult animals [28].

Regarding the volumetric proportions, which are directly proportional to sperm production [8], it can be seen that in mammals the seminiferous tubules represent $60 \%$ to $90 \%$ of the volume of the testicle [30], with the remainder being filled by intertubular tissue, which contains Leydig cells and stroma [8].

The volumetric rate of testicular parenchyma components varies greatly among species, mainly the percentage values taken by seminiferous tubules and Leydig cells. This variation is one of the major factors responsible for the difference observed for efficiency in sperm production in several species [8] [28].

In the present study, the values observed for the volumetric proportions of the testicular parenchyma constituents were in line with those observed by Andreussi et al. [1], with $80.9 \%$ of the testicular parenchyma occupied by seminiferous tubules. However, this result differed from the overall average of all other breeds as, according to Andreussi et al. [1], animals of the Nelore breed had a higher volume of seminiferous tubules compared to all other Zebu breeds studied.

Lower volumetric proportions of these components were observed in Dutch bulls [20] [21], with young bulls averaging $76.8 \%$ and bulls over 4 years old averaging $73 \%$.

In rats, the volumetric proportion of seminiferous tubules is quite similar to cattle [31], but Russell and França [32] found that a greater proportion (85.8\%) of the testicular volume was made up of seminiferous tubules in rats.

Regarding the three measurements evaluated for the seminiferous tubules (length, epithelium height, and diameter), no differences were observed among the Gir cattle in the present study. Similarly, no differences were observed in Andreussi et al. [1] within in the Gir breed specifically and among all the zebu breeds studied, although animals of the Nelore breed had the largest measurements among the zebuine cattle. In rats, the diameter of the seminiferous tubules is larger [31]. The diameter of the seminiferous tubules can suffer alterations caused by the multiplication of Sertoli cells. Thus, a study by Berndtson and Jones [33] found that higher testicular weight, greater number of germ cell populations, greater number of Sertoli cells, and consequently higher sperm production were positively correlated.

In an experiment with adult Bos taurus, it was demonstrated that heavier testicles have a higher number of rounded spermatozoa per Sertoli cell [34] and higher daily sperm production [29].

In the present study, Sertoli cell and spermatogonia populations showed few variations between the animals evaluated. The average number of Sertoli cells 
observed was four per seminiferous tubule cross-section during stage 1 of CES and in the mean number of spermatogonia cells was two per cross-section, which were similar to the numbers observed as general averages by Andreussi et al. [2] in the Nelore, Nelore mocho, Gir, Guzerá, and Tabapuã breeds, in addition to by Dias [35]. However, with the progression of cell differentiation in spermatogenesis it is possible notice differences between the numbers of spermatocytes in preleptotene/leptotene, pachytene and rounded spermatocytes between the two studies mentioned above, i.e. the final yield in spermatogenesis is different between the breeds, with the Nelore breed producing the greatest final spermatogenesis yield [2]. On the other hand, Aguiar et al. [36] (2006) analyzed bulls of the Angus breed and observed a lower number of Sertoli cells, with 2.8 cells per cross-section. Santos et al. [37] reported a count of 12.93 Sertoli cells per section in Bos indicus, however a different methodology than that applied in most other the studies was used, and Aguiar et al. [36] observed an average of 26.5 Sertoli cells per section in bulls of the Angus breed at 22 weeks of age.

The proportion of Leydig cells is very variable in mammals, with reports of $2.2 \%$ in rats [8] and $20 \%$ to $60 \%$ in pigs [38]. Amann [20] observed that the volumetric proportion occupied by Leydig cells in the intertubular space was $5 \%$ in young 3-year-old Dutch bulls, and in bulls above 4 years the value was $7 \%$.

Spermatogenesis is functionally dependent on Sertoli cells and Leydig cells for hormone support [39] [40]. According to França and Russell [8], Sertoli cells represent $16.2 \%$ of the total testicle volume.

Results published in rats [31] differ from those observed in bulls in the present study. In the aforementioned study, the number of primary spermatocytes in the pachytene of rats was 21.37 cells, versus 33.3 in bulls, and 70.26 rounded spermatids in rats versus 92.0 cells in Gir bulls.

Regarding the corrected cell populations within the CSE, Almeida et al. [31] showed that the ratio of rounded spermatocytes to spermatocytes in the pachytene was close to that observed in the present study (3.1) in rats, while a ratio of 2.78 was observed in Gir cattle in the present study.

In the current experiment, regarding the relationship between the cell populations in the seminiferous tubules and cell losses during the spermatogenic process (Table 5 and Table 6), it was noted that the vast majority of losses occurred during mitosis, at an average of around $75.5 \%$ compared to the $30.6 \%$ observed during the meiotic phase. The results are similar to those observed by Andreussi et al. [2] in the Gir, Nelore, Nelore Mocho, Guzerá, and Tabapuã breeds, with the results for the Gir breed, specifically, being more similar. The mean total loss in spermatogenesis did not differ between the two studies. However, specifically in the standard Nelore breed, it is necessary to stress that the total losses in spermatogenesis were lower than in the other breeds, with a final loss of $75.6 \%$ [2].

Understanding spermatogenesis and its testicular physiology are fundamental for the identification of potential causes of infertility and subfertility, and under- 
standing the processes that define the capacity of sperm production are crucial parts of this process.

In this research, the animals presented on average a total daily sperm production of $14.8 \times 10^{9}$ cells, with a standard deviation of $2.0 \times 10^{9}$. In Andreussi et al. [2], the values were similar to those obtained for the Gir breed and close for those noted for the Tabapuã and Guzerá breeds, however sperm production was greater in bulls of the Nelore breed, suggesting that the fertility enhancement efforts are more advanced in this breed.

It appears that the other zebuine breeds mentioned in this study (Gir, Guzerá, and Tabapuã) have spermatogenesis numbers far below the potential capacity of each breed. The superiority of the Nelore breed in comparison to other breeds can be understood in this aspect as a result of the more intense selection process applied to this breed, a fact that can be appreciated in figures: in 2017, according to the Brazilian Association of Zebu Breeders [41], there were 807 Nelore bulls in semen collection centers, a number much higher than that of the Gir (81), Tabapuã (77), and Guzerá (81) breeds. Other interesting data are those published by Brazilian Association of Artificial Insemination [42], which indicate that in 2014, 629,150 doses of semen from the Gir breed, 162,056 from Guzerá, 120,280 doses from Tabapuã, and 3,235,979 doses of semen from the Nelore breed were sold. The data presented suggest that intensifying the genetic improvement efforts applied to the Gir breed could increase the spermatogenesis rate in this breed.

\section{Conclusion}

The Gir bulls of this research presented a means of $289.2 \pm 30.5 \mathrm{~g}$ of total testicular weight, $17.0 \pm 0.8 \mathrm{~m}$ of tubular length per g/testicle, seminiferous tubules and intertubular tissue volumetric proportions, which were respectively $80.9 \% \pm$ $1.7 \%$ and $19.1 \% \pm 1.7 \%$. Ratios between the corrected germ cell numbers per seminiferous tubule cross-section in stage 1 of the Gir bull cycle of seminiferous epithelium and total daily sperm production were within the averages reported for zebuine cattle breeds.

\section{Conflicts of Interest}

The authors declare no conflicts of interest regarding the publication of this paper.

\section{References}

[1] Andreussi, P.A.T., Costa, D.S., Faria, F.J.C., Fernandes, C.A.C., Santos, M.D. and Silva, J.C.B. (2014) Testicular Histomorphometric Evaluation of Zebu Bull Breeds. Brazilian Archives of Biology and Technology, 57, 900-907. https://doi.org/10.1590/S1516-8913201402262

[2] Andreussi, P.A.T., Costa, D.S., Faria, F.J.C., Fernandes, C.A.C. and Guimarães, J.D. (2013) Efficiency of the Spermatogenesis in Zebu Bulls (Bos taurus indicus). Ana- 
tomia, Histologia, Embryologia, 43, 133-140.

[3] Santiago, A. A. (1983) O Nelore. Ed. dos Criadores, São Paulo, 583 p.

[4] Santos, R. (1998) O zebu-Edição comemorativa dos 60 anos do registro genealógico, ABCZ-Associação Brasileira dos Criadores de Zebu, Brazil, 856 p.

[5] Bergmann, J.A.G. (1993) Melhoramento genético da eficiência Reprodutivaembovinos de corte. Congresso Brasileiro de Reprodução Animal, CBRA, Belo Horizonte, 70-86.

[6] Instituto Brasileiro de Geografia e Estatística (2015) Produção da pecuária Municipal 2015. Rio de Janeiro, 43, 13-16.

[7] Folhadella, I.M., Sá, W.F., Ferreira, A.M., Camargo, L.S.A., Viana, J.H.M, Ramos, A.A. and Silva, M.V.G.B. (2006) Características Andrológicas de Touros da raça Gir. Arquivo Brasileiro de Medicina Veterinária e Zootecnia, 58, 809-815. https://doi.org/10.1590/S0102-09352006000500016

[8] França, L.R. and Russell, L.D. (1998) The Testis of Domestic Animals. In: Regadera, J. and Martinez-Garcia, F., Eds., Male Reproduction: A Multidisciplinary Overview, Churchill Livingstone, Madrid, 197-219.

[9] Courot, M., Hochereau-De Reviers, M.T. and Ortavant, R. (1970) Spermatogenesis. In: Johnson, A.D., Gomes, W.R. and VanDemark, N.L., Eds., The Testis, Academic Press, New York, 1, 339-432. https://doi.org/10.1016/B978-0-12-386601-1.50012-3

[10] Russell, L.D., Ettlin, R., Sinha Hikim, A. and Clegg, E. (1990) Histological and Histopathological Evaluation of the Testis. Cache River Press, Clearwater.

[11] Leblond, C.P. and Clermont, Y. (1952) Definition of the Stages of the Cycle of the Seminiferous Epithelium in the Rat. Annals of the New York Academy of Sciences, 55, 548-573.

[12] Cardoso, F.M. (1977) Desenvolvimento dos órgãos Genitais Masculinos de Zebus (Bos indicus), da raça Nelore, do período Fetal aos 36 meses de idade. Dissertação (Mestrado em Morfologia)-Escola de Veterinária/Universidade Federal de Minas Gerais, Belo Horizonte, 140p.

[13] Costa, D.S., Henry, M. and Paula, T.A.R. (2004) Espermatogênese de Catetos ( Tayassu tajacu). Arquivo Brasileiro de Medicina Veterinária e Zootecnia, 56, 46-51. https://doi.org/10.1590/S0102-09352004000100008

[14] Johnson, L., Petty, C.S. and Neaves, W.B. (1981) A New Approach to Quantification of Spermatogenesis and Its Application to Germinal Cell Attrition during Human Spermiogenesis. Biology of Reproduction, 25, 217-226.

https://doi.org/10.1095/biolreprod25.1.217

[15] Rasband, W. National Institute of Healh, USA. Software. http://rsb.info.nih.gov/ij/

[16] Attal, J. and Courot, M. (1963) Développement Testiculaire et établissement de la Spermatogénèse chez le taureau. Annales de Biologie Animale, Biochimie, Biophysique, 3, 219-241.

[17] Amann, R.P. (1981) A Critical Review of Methods for Evaluation of Spermatogenesis from Seminal Characteristics. Journal of Andrology, 2, 37-58.

[18] Ortavant, R., Courot, M. and Hochereau-De Reviers, M.T. (1977) Spermatogenesis in Domestic Mammals. In: Cole, H.H. and Cupps, P.T., Eds., Reproduction in Domestic Animals, Academic Press, New York, 203-227.

[19] Abercrombie, M. (1946) Estimation of Nuclear Populations from Microtome Sections. The Anatomical Record, 94, 239-247.

[20] Amann, R.P. (1962) Reproductive Capacity of Dairy Bulls. III. The Effect of Ejacu- 
lation Frequency, Unilateral Vasectomy, and Age on Spermatogenesis. American Journal of Anatomy, 110, 49-67.

[21] Amann, R.P. and Almquist, J.O. (1962) Reproductive Capacity of Dairy Bulls. VIII. Direct and Indirect Measurement of Testicular Sperm Production. Journal of Dairy Science, 45, 774-781. https://doi.org/10.3168/jds.S0022-0302(62)89487-9

[22] Cardoso, F.M. (1981) Morfologia, Cinética e Quantificação da Espermatogênese em zebu (Bos indicus). Universidade Federal de Minas Gerais, Belo Horizonte, 208 p.

[23] Ayres, M., Ayres Jr., M., Ayres, D.L. and Santos, A.S. (2003) BioEstat. Aplicações Estatísticas nas áreas das ciências Biológicas e médicas. Sociedade Civil Maniraua, Belém.

[24] Amann, R.P. (1961) Reproductive Physiology of the Male Bovine. The Pennsylvania State University, University Park.

[25] Murta, D.V., Costa, D.S., Santos, M.D. and Faria, F.J.C. (2010) Somatic and Germ Cell Proliferation during Post-Natal Development of the Testis in the Wild Boar (Sus scrofa scrofa). Animal Reproduction Science, 119, 154-159.

https://doi.org/10.1016/j.anireprosci.2009.11.003

[26] Macedo, D.B., Costa, D.S., Paula, T.A.R., Santos, M.D. and Faria, F.J.C. (2011) Testicular Biometry of Free-Ranging Feral Pigs (Sus scrofa scrofa). The Revista Brasileira de Saúde e Produção Animal, 12, 381-388.

[27] Swierstra, E.E. (1966) Structural Composition of Shorthorn Bull Testes and Daily Spermatozoa Production as Determined by Quantitative Testicular Histology. Canadian Journal of Animal Science, 46, 107-119. https://doi.org/10.4141/cjas66-016

[28] Costa, D.S., Paula, T.A.R. and Matta, S.L.P. (2006) Cat, Cougar, and Jaguar Spermatogenesis: A Comparative Analysis. Brazilian Archives of Biology and Technology, 49, 725-731. https://doi.org/10.1590/S1516-89132006000600006

[29] Berndtson, W.E., Igboeli, G. and Parkerm, W.G. (1987) The Numbers of Sertoli Cells in Mature Holstein Bulls and Their Relationship to Quantitative Aspects of Spermatogenesis. Biology of Reproduction, 37, 60-67.

https://doi.org/10.1095/biolreprod37.1.60

[30] Setchell, B.P. (1982) Spermatogenesis and Spermatozoa. In: Austin, C.R. and Short, R.V., Eds., Reproduction in Mammaliam, Vol. 1, Pual Elek Books, London, 63-101.

[31] Almeida, L.M., Weiss, R.R., Castro, C.S. and Buchele, J. (2000) Quantificação Histológica da Espermatogênese de ratos Wistar Tratados com dimetil sulfóxido. Archives of Veterinary Science, 5, 129-135. https://doi.org/10.5380/avs.v5i1.3897

[32] Russell, L.D. and França, L.R. (1995) Building a Testis. Tissue \& Cell, 27, 129-147. https://doi.org/10.1016/S0040-8166(95)80016-6

[33] Berndtson, W.E. and Jones, L.S. (1989) Relationship of Intratesticular Testosterone Content of Stallions to Age, Spermatogenesis, Sertoli Cell Distribution and Germ Cell-Sertoli Cell Ratios. Reproduction, 85, 511-518. https://doi.org/10.1530/jrf.0.0850511

[34] Moura, A.A. and Erickson, B.H. (1999) Respostas Hormonais ao Tratamento com GnRH e estradiol e suas correlações com Desenvolvimento Testicular e número de células de Sertoli em touros Angus x Charolês na fase de pré-puberdade. Revista Brasileira de Zootecnia, 28, 35-43. https://doi.org/10.1590/S1516-35981999000100006

[35] Dias, W. (2015) Ecotextura testicular e suas correlações com a espermatogênese de touros Nelore. Dissertação (Mestrado em Ciência Animal)_Faculdade de Medicina 
Vaterinária e Zootenia/UFMS Campo Grande, MS, 31 p.

[36] Aguiar, G.V., Araújo, A.A. and Moura, A.A.A. (2006) Desenvolvimento testicular, espermatogênese e concentrações hormonais em touros Angus. Revista Brasileira de Zootecnia, 35, 1629-1638. https://doi.org/10.1590/S1516-35982006000600008

[37] Santos, R.L., Silva, C.M., Ribeiro, A.F.C., Vasconcelos, A.C., Pesquero, J.L., Coelho, S.G., Serakides, R. and Reis, S.R. (1999) Effect of Growth Hormone and Induced IGF-I Release on Germ Cell Population and Apoptosis in the Bovine Testis. Theriogenology, 51, 957-984. https://doi.org/10.1016/S0093-691X(99)00043-6

[38] Fawcett, D.W., Neaves, W.B. and Flores, M.N. (1973) Comparative Observations on Intertubular Lymphatic and the Organization of the Interstitial Tissue of the Mammalian Testis. Biology of Reproduction, 9, 500-532.

https://doi.org/10.1093/biolreprod/9.5.500

[39] Martin-du Pan, R.C. and Campana, A. (1993) Physiopathology of Spermatogenic Arrest. Fertility and Sterility, 60, 937-946. https://doi.org/10.1016/S0015-0282(16)56388-2

[40] Sharpe, R.M. (1994) Regulation of Espermatogenesis. In: Knobil, E. and Neill, J.D., Eds., The Phisiology of Reproduction, Vol. 1, 2nd Edition, Raven Press, New York, 1364-1434.

[41] Associação Brasileira de Criadores de Zebu (2017) Sumário nacional de avaliação genética-2017. Programa de Melhoramento Genético de Zebuínos (PMGZ). http://www.abcz.org.br/Home/Secao/155-Consultar-Avaliacoes-Geneticas

[42] Associação Brasileira de Inseminação Artificial (2017) Índex ASBIA-Importação, Exportação e comercialização de sêmen, 17-18.

http://www.asbia.org.br/novo/upload/mercado/index2014.pdf 